\title{
Extrascleral Extension of Uveal Melanoma
}

National Cancer Institute

\section{Source}

National Cancer Institute. Extrascleral Extension of Uveal Melanoma. NCI Thesaurus.

Code C111028.

Spread of uveal melanoma beyond the sclera. 